\section{Terakreditasi}

Ditjen Penguatan Riset dan Pengembangan, Kemenristekdikti

Keputusan No: 21/E/KPT/2018, Tanggal 9 Juli 2018
Mei 2020, 7(2):127-132

DOI: http://dx.doi.org/10.33772/jitro.v7i2.11482

http://ojs.uho.ac.id/index.php/peternakan-tropis

\title{
Evaluasi Kecernaan In Vitro Bahan Kering dan Bahan Organik Kulit Singkong Fermentasi Sebagai Bahan Pakan Ternak
}

\section{Firman Nasiu, Wa Laili Salido, Andi Murlina Tasse, Syamsuddin, Hairil A. Hadini, Amiluddin Indi}

\author{
Jurusan Peternakan, Fakultas Peternakan, Universitas Halu Oleo \\ Jl. H.E.A. Mokodompit Kampus Hijau Bumi Tridharma, Anduonohu, Kendari 93232 \\ Email korespondensi: firman_nasiu@yahoo.com
}

(Diterima 16-03-2020; disetujui 08-05-2020)

\begin{abstract}
ABSTRAK
Penelitian ini bertujuan untuk melakukan evaluasi kecernaan in vitro bahan kering dan bahan organik kulit singkong yang difermentasi menggunakan jamur Aspergillus niger dan EM-4 sehingga dapat memberikan informasi tambahan mengenai kualitas kulit siongkong yang difermentasi maupun tanpa fermentasi. Rancangan penelitian yang digunakan adalah rancangan acak lengkap (RAL) yang terdiri atas 4 perlakuan dan 4 ulangan. Perlakuan yang diberikan terhadap kulit singkong adalah P1 (tanpa fermentasi), P2 (fermentasi dengan Aspergillus niger), P3 (fermentasi dengan EM-4), P4 (fermentasi dengan kombinasi $A$. niger dan EM-4). Evaluasi kecernaan in vitro ini dilakukan dengan menggunakan metode Tilley and Terry. Hasil penelitian menunjukkan bahwa penambahan jamur $A$. niger dan EM-4 dalam proses fermentasi kulit singkong dapat meningkatkan kecernaan bahan kering dan bahan kering kulit singkong secara signifikan dimana hasil terbaik diperoleh pada penambahan kombinas A. niger dan EM-4.
\end{abstract}

Kata kunci: Aspergillus niger, bahan kering, bahan organik, EM-4, kecernaan in vitro

\begin{abstract}
The aim of this study was to evaluate the in vitro digestibility of dry matter and organic matter of fermented cassava peel using Aspergillus niger and EM-4 inoculant to provide additional information about the quality of fermented and unfermented cassava peel. The study design used was a completely randomized design (CRD) consisting of 4 treatments and 4 replications. The treatments were P1 (without fermentation), P2 (fermented with Aspergillus niger), P3 (fermented with EM-4), P4 (fermented with a combination of $A$. niger and EM-4). This in vitro digestibility evaluation was conducted by using the Tilley and Terry method. The results showed that the addition of A. niger fungi and EM-4 in the fermentation process of cassava peel could significantly improve the digestibility of dry matter and dry matter of cassava peel where the best results were obtained on the addition of A. niger and EM-4 combinations.
\end{abstract}

Keywords: Aspergillus niger, dry matter, EM-4, in vitro digestibility, organic matter

\section{PENDAHULUAN}

Pemanfaatan kulit singkong sebagai bahan pakan ternak mulai banyak dilakukan masyarakat terutama di daerah-daerah penghasil singkong, namun penggunaannya masih terbatas karena rendahnya kandungan nutrisi (Mirwandhono et al., 2006; Antari \& Umiyasih, 2009) dan adanya zat antinutrisi berupa sianida yang diketahui dapat membahayakan kesehatan ternak apabila dikonsumsi dalam jumlah berlebihan (Yildiz et al., 2017). Sianida dapat bersifat racun baik pada manusia maupun hewan karena dapat menyebab- kan terhentinya pembentukan energi dan kerusakan jaringan akibat kekurangan energi (Zagrobelny et al., 2004).

Perbaikan kualitas kulit singkongsebagai bahan pakan ternak dapat dilakukan melalui penerapan teknologi fermentasi karena dengan bantuan mikroorganisme dapat membantu mempertahankan kandungan nutrisi selama proses fermentasi dan membatu menurunkan kadar sianida. Jamur Aspergillus niger (Mirwandhono et al., 2006) dan bakteri asam laktat (Adeleke et al., 2017) merupakan jenis mikroorganisme yang dapat digunakan dalam proses fermentasi kulit singkong 
karena dapat membantu meningkatkan nilai nutrisi serta mereduksi kadar sianida sehingga relatif aman dikonsumsi oleh ternak. Perlakuan dengan proses fermentasi tersebut diharapkan dapat meningkatkan nilai nutrisi kulit singkong sehingga dapat meningkatkan pemanfaatan kulit singkong sebagai salah satu bahan pakan ternak serta membantu penanggulangan limbah pengolahan hasil olahan tanaman singkong penyebab pencemaran tanah.

Penelitian ini bertujuan untuk melakukan evaluasi kecernaan in vitro bahan kering dan bahan organik kulit singkong yang difermentasi menggunakan jamur Aspergillus niger dan EM-4 sehingga dapat memberikan informasi tambahan mengenai kualitas kulit siongkong baik yang difermentasi maupun tanpa fermentasi yang akan digunakan sebagai bahan pakan ternak sehingga dapat lebih meningkatkan pemanfaatan limbah kulit singkong. Informasi tersebut dapat menambah pengetahuan dan pemahaman masyarakat sehingga akan menghilangkan kekhawatiran penggunaan kulit singkong sebagai pakan ternak.

\section{MATERI DAN METODE}

\section{Materi Penelitian}

Alat dan bahan yang digunakan dalam penelitian ini adalah kulit singkong, jamur Aspergillus niger, larutan EM-4, toples kaca, gunting, alat penggiling, timbangan analitik, peralatan dan bahan kimia analisis proksimat dan analsis kadar sianida.

\section{Metode Penelitian}

\section{Penyiapan Kulit Singkong}

Kulit singkong dicuci, dibersihkan dari kotoran tanah kemudian dijemur di bawah sinar matahari sampai kering. Selanjutnya kulit singkong yang sudah kering digiling halus sehingga menjadi tepung kulit singkong (Mirwandhono et al., 2006).

Fermentasi Kulit Singkong dengan Aspergillus niger (KSFan)

Tahap pertama yang dilakukan adalah mencampur tepung kulit singkong dengan jamur Aspergillus niger sebanyak 1\% (Semaun, 2013) lalu dimasukkan ke dalam toples percobaan sambil terus dipadatkan kemudian ditutup rapat. Proses pemeraman (fermentasi) akan dilakukan selama 21 hari (Budiarsana et al., 2006) sampai dihasilkan kulit singkong fermentasi. Setelah 21 hari, toples wadah fermentasi kemudian dibuka dan kulit singkong fermentasi selanjutnya dilakukan analisis kadar bahan kering dan bahan organik (AOAC,
2005) dan kecernaan in vitro bahan kering dan bahan organik (Tilley \& Terry, 1963)

Fermentasi Kulit Singkong dengan Effective Microorganisms (EM) (KSFem)

Kegiatan awal yang dilaksanakan adalah melakukan aktivasi larutan EM-4 dengan mencampur larutan EM-4 $25 \mathrm{ml}$ : pelarut air 2500 $\mathrm{ml}$ : gula pasir 250 gram (Telew et al., 2012), selanjutnya diinkubasi tertutup selama 24 jam (Iqbal et al. 2016). Selanjutnya mencampur tepung kulit singkong dengan larutan EM dengan perbandingan setiap 1000 gram tepung kulit singkong akan disemprot dengan $1000 \mathrm{ml}$ larutan $E M$ yang telah diaktivasi (Telew et al., 2012), selanjutnya dimasukkan ke dalam toples percobaan sambil terus dipadatkan kemudian ditutup rapat. Pemeraman (proses fermentasi) akan dilakukan selama 21 hari (Budiarsana et al., 2006) sampai dihasilkan kulit singkong fermentasi. Setelah 21 hari, toples wadah fermentasi kemudian dibuka dan kulit singkong fermentasi selanjutnya dilakukan analisis kadar bahan kering dan bahan organik (AOAC, 2005) serta kecernaan in vitro bahan kering dan bahan organik (Tilley \& Terry, 1963)

\section{Fermentasi Kulit Singkong dengan Aspergillus niger dan Effective Micro- organisms (KSFanem)}

Kegiatan diawali dengan melakukan aktivasi larutan $E M$ dengan mencampur larutan EM $25 \mathrm{ml}$ : pelarut air $2500 \mathrm{ml}$ : gula pasir 250 gram (Telew et al., 2012), selanjutnya diinkubasi tertutup selama 24 jam (Iqbal et al., 2016). Langkah selanjutnya adalah mencampur tepung kulit singkong dengan jamur Aspergillus niger sebanyak 1\% (Semaun, 2013) dan larutan EM dengan perbandingan setiap 1000 gram tepung kulit singkong akan disemprot dengan $1000 \mathrm{ml}$ larutan EM yang telah diaktivasi (Telew et al., 2012). Campuran tepung kulit singkong, Aspergillus niger, dan EM selanjutnya dimasukkan ke dalam toples percobaan sambil terus dipadatkan kemudian ditutup rapat. Pemeraman (proses fermentasi) akan dilakukan selama 21 hari (Budiarsana et al., 2006) sampai dihasilkan kulit singkong fermentasi.

Setelah 21 hari toples wadah fermentasi kemudian dibuka dan kulit singkong fermentasi selanjutnya dilakukan analisis kadar bahan kering dan bahan organik (AOAC, 2005) serta kecernaan in vitro bahan kering dan bahan organik (Tilley \& Terry, 1963) 


\section{Analisis Data dan Rancangan Percobaan}

Rancangan yang akan digunakan dalam penelitian ini adalah Rancangan Acak Lengkap yang terdiri atas 4 perlakuan dan 4 ulangan sebagai berikut:

KSTF : kulit singkong tanpa fermentasi

KSFan : kulit singkong terfermentasi Aspergillus niger

KSFem : kulit singkong terfermentasi EM-4

KSFanem: kulit singkong terfermentasi

Aspergillus niger dan EM-4

Data yang diperoleh akan dianalisis sidik ragam (ANOVA), apabila terdapat pengaruh yang nyata akan dilanjutkan dengan Duncan Multiple Range Test (DMRT).

\section{HASIL DAN PEMBAHASAN}

\section{Kadar Bahan Kering}

Hasil analisis kadar bahan kering kulit singkong yang difermentasi menggunakan jamur Aspergillus niger, EM-4, dan kombinasi A.niger dan EM-4 disajikan pada Tabel 1.

Hasil analisis ragam menunjukkan bahwa penambahan A. niger, EM-4, maupun kombinasi A. niger dan EM-4 dalam proses fermentasi berpengaruh sangat nyata terhadap penurunan kadar bahan kering kulit singkong fermentasi. Bahan kontrol yang tidak difermentasi (P0) memiliki kandungan bahan kering yang lebih tinggi dibandingkan dengan bahan yang difermentasi. Hal tersebut dapat disebabkan karena dalam proses fermentasi, mikroorganisme menggunakan bahan kering substrat untuk dijadikan sebagai sumber energi dalam proses pertumbuhan dan perkembangan mikroorganisme itu sendiri (Umiyasih \& Anggraeni, 2008), sehingga menyebabkan penurunan kadar bahan kering pada kulit singkong yang difermentasi. Selain itu, penambahan mikroorganisme dapat memicu peningkatan aktivitas fermentasi yang menyebabkan terjadinya peningkatan produksi air $\left(\mathrm{H}_{2} \mathrm{O}\right)$ (Cabrol et al., 2017) sehingga menurunkan kadar bahan kering bahan. Selanjutnya Zumael (2009) menyatakan bahwa penggunaan nutrient oleh mikroorganisme sebagai sumber karbon, nitrogen, dan mineral serta dilepaskannya $\mathrm{CO}_{2}$ dan energy dalam bentuk panas yang menguap bersama partikel air dapat menyebabkan terjadinya penurunan kandungan bahan kering selama proses fermentasi.

\section{Kadar BahanOrganik}

Hasil analisis kadar bahan organik kulit singkong yang difermentasi menggunakan jamur Aspergillus niger, EM-4, dan kombinasi A.niger dan EM-4 disajikan pada Tabel 2.

Tabel 1. Hasil Analsis Kadar Bahan Kering Kulit Singkong Fermentasi

\begin{tabular}{ccccc}
\hline \multirow{2}{*}{ Ulangan } & \multicolumn{3}{c}{ Perlakuan } \\
\cline { 2 - 5 } & KSTF & KSFan & KSFem & KSFanem \\
\hline 1 & 87,22 & 57,55 & 56,94 & 53,26 \\
2 & 87,27 & 57,47 & 57,40 & 55,20 \\
3 & 87,25 & 58,48 & 56,88 & 53,42 \\
4 & 87,52 & 57,56 & 56,59 & 53,33 \\
Rata-rata & $87,32 \pm 0,14^{\mathrm{a}}$ & $57,77 \pm 0,48^{\mathrm{b}}$ & $56,95 \pm 0,34^{\mathrm{b}}$ & $53,80 \pm 0,93^{\mathrm{c}}$ \\
\hline
\end{tabular}

Ket : a,b,c, huruf yang berbeda pada baris yang sama menunjukkan perbedaan pengaruh yang sangat nyata $(\mathrm{P}<0,01)$; KSTF (Kulit Singkong Tanpa Fermenetasi); KSFan (Kulit Singkong Fermentasi dengan Aspergillus niger); KSFem (Kulit Singkong Fermentasi dengan EM-4); KSFanem (Kulit Singkong Fermentasi Aspergillusniger dan EM-4)

Tabel 2. Hasil Analsis Kadar Bahan Organik Kulit Singkong Fermentasi

\begin{tabular}{ccccc}
\hline \multirow{2}{*}{ Ulangan } & \multicolumn{3}{c}{ Perlakuan } \\
\cline { 2 - 5 } & KSTF & KSFan & KSFem & KSFanem \\
\hline 1 & 89,55 & 90,19 & 90,24 & 91,14 \\
3 & 89,09 & 89,87 & 90,83 & 90,24 \\
4 & 88,55 & 89,67 & 91,16 & 90,75 \\
Rata-rata & 87,62 & 90,66 & 90,43 & 90,04 \\
\hline
\end{tabular}

Ket : a,b, huruf yang berbeda pada baris yang sama menunjukkan perbedaan sangat nyata $(\mathrm{P}<0,01)$; KSTF (Kulit Singkong Tanpa Fermenetasi); KSFan (Kulit Singkong Fermentasi dengan Aspergillus niger); KSFem (Kulit Singkong Fermentasi dengan EM-4); KSFanem (Kulit Singkong Fermentasi Aspergillusniger dan EM-4) 
Hasil sidik ragam menunjukkan bahwa penambahan A. niger, EM-4, maupun kombinasi A. niger dan EM-4 dalam proses fermentasi berpengaruh sangat nyata terhadap peningkatan kadar bahan organik kulit singkong fermentasi. Peningkatan kandungan bahan organik pada kulit singkong yang difermentasi dapat disebabkan karena selama proses fermentasi, mikroorganisme yang terlibat dalam proses fermentasi mengalami pertumbuhan dan perkembangan yang signifikan sehingga biomassa mikroorganisme yang mengandung bahan-bahan organik tersebut menambah kandungan bahan organik pada kulit singkong fermentasi. Mulyono et al., (1989) menyatakan bahwa biomassa merupakan wujud massa dari hasil proses biologis dari mikroorganisme yang mampu mengkorversi bahan menjadi protein. Selanjutnya, jenis dan jumlah mikroorganisme yang lebih beragam pada perlakuan fermentasi dengan kombinasi A. niger dan EM-4 dapat meningkatkan kandungan bahan organik bahan sebagaimana Stephanie \& Purwadaria (2013), bahwa proses dan produk fermentasi dapat dipengaruhi oleh jenis dan jumlah starter yang digunakan selama proses fermentasi.

\section{Kecernaan In Vitro Bahan Kering}

Hasil evaluasi kecernaan bahan kering in vitro kulit singkong yang difermentasi menggunakan jamur Aspergillus niger, EM-4, dan kombinasi A.niger dan EM-4 disajikan pada Tabel 3.

Hasil analisis ragam menunjukkan bahwa penambahan A. niger, EM-4, maupun kombinasi
A. niger dan EM-4 dalam proses fermentasi berpengaruh sangat nyata terhadap peningkatan kecernaan in vitro bahan kering kulit singkong fermentasi. Kecernaan bahan kering in vitro tertinggi terdapat pada perlakuan fermentasi dengan menggunakan kombinasi A. niger dan EM 4. Hal tersebut dapat disebabkan karena baik jamur A. niger (Anwar et al., 2010) maupun mikroorganisme yang terkandung di dalam larutan EM-4 memiliki kemampuan melonggarkan ikatan lignoselulosa yang terdapat pada serat kasar substrat sehingga lebih mudah dicerna oleh enzimenzim percernaan yang dihasilkan oleh mikroorganisme dalam cairan rumen selama proses inkubasi in vitro. Jamur Aspergillus niger merupakan strain jamur yang dapat digunakan untuk mendegradasi limbah pertanian dengan lebih efisien (Jahromi et al., 2010) dan degradasi fraksi lignoselulosa yang terkandung dalam kulit singkong dapat dilakukan dengan menggunakan enzim selulase yang dihasilkan oleh jamur Aspergillus niger. Selain itu, mikroorganisme yang terdapat larutan EM-4 juga berperanan penting dalam hidrolisis serat kasar substrat (Telew et al., 2013) sehingga dapat membantu meningkatkan kecernaan bahan kering secara in vitro.

\section{Kecernaan In Vitro Bahan Organik}

Hasil evaluasi kecernaan bahan organik in vitro kulit singkong yang difermentasi menggunakan jamur Aspergillus niger, EM-4, dan kombinasi A.niger dan EM-4 disajikan pada Tabel 4.

Tabel 3. Hasil Analsis Kecernaan In vitroBahan Kering Kulit Singkong Fermentasi

\begin{tabular}{ccccc}
\hline \multirow{2}{*}{ Ulangan } & \multicolumn{3}{c}{ Perlakuan } \\
\cline { 2 - 5 } & KSTF & KSFan & KSFem & KSFanem \\
\hline 1 & 58,75 & 61,19 & 62,74 & 64,44 \\
2 & 59,35 & 61,10 & 64,42 & 66,05 \\
3 & 58,84 & 62,02 & 62,93 & 65,42 \\
4 & 60,28 & 60,11 & 63,44 & 66,00 \\
Rata-rata & $59,31 \pm 0,70^{\mathrm{a}}$ & $61,11 \pm 0,78^{\mathrm{b}}$ & $63,38 \pm 0,75^{\mathrm{c}}$ & $65,48 \pm 0,75^{\mathrm{d}}$ \\
\hline
\end{tabular}

Ket : a,b,c, d, huruf yang berbeda pada baris yang sama menunjukkan perbedaan pengaruh yang sangat nyata $(\mathrm{P}<0,01)$; KSTF (Kulit Singkong Tanpa Fermenetasi); KSFan (Kulit Singkong Fermentasi dengan Aspergillus niger);

KSFem (Kulit Singkong Fermentasi dengan EM-4); KSFanem (Kulit Singkong Fermentasi Aspergillusniger dan EM-4)

Tabel 4. Hasil Analsis Kecernaan In vitro Bahan Kering Kulit Singkong Fermentasi

\begin{tabular}{ccccc}
\hline \multirow{2}{*}{ Ulangan } & \multicolumn{3}{c}{ Perlakuan } \\
\cline { 2 - 5 } & KSTF & KSFan & KSFem & KSFanem \\
\hline 1 & 61,86 & 65,16 & 66,31 & 68,15 \\
3 & 63,61 & 64,98 & 67,40 & 69,29 \\
4 & 62,89 & 66,31 & 66,37 & 69,39 \\
Rata-rata & 63,70 & 63,94 & 67,39 & 70,29 \\
\hline Ket & $63,02 \pm 0,85^{\mathrm{a}}$ & $65,10 \pm 0,97^{\mathrm{b}}$ & $66,87 \pm 0,61^{\mathrm{b}}$ & $69,28 \pm 0,88^{\mathrm{c}}$ \\
\hline
\end{tabular}

Ket : a, b, c, d, huruf yang berbeda pada baris yang sama menunjukkan perbedaan pengaruh yang sangat nyata $(\mathrm{P}<0,01)$; KSTF (Kulit Singkong Tanpa Fermenetasi); KSFan (Kulit Singkong Fermentasi dengan Aspergillus niger);KSFem (Kulit Singkong Fermentasi dengan EM-4); KSFanem (Kulit Singkong Fermentasi Aspergillusniger dan EM-4) 
Hasil analsis ragam menunjukkan bahwa kecernaan in vitro bahan organik kulit singkong fermentasi, dengan perlakuan penambahan $A$. niger, EM-4, maupun kombinasi A. niger danEM-4 dalam proses fermentasi, mengalami peningkatan secara signifikan. Hal tersebut dapat disebabkan oleh terjadinya peningkatan jumlah nutrien (Wikanatsri et al., 2012; Stephanie \& Purwadaria, 2013) yang tersedia bagi pertumbuhan dan perkembangan mikroorganisme dalam cairan rumen in vitro sebagai dampak dari proses fermentasi yang telah dilaksanakan oleh jamur $A$. niger (Jahromi et al., 2010) dan EM-4 (Telew et al., 2013) sebelum substrat diuji secara in vitro. Proses fermentasi bahan kulit singkong oleh jamur A. niger dan EM-4 menyebabkan bahan-bahan organik substrat dirombak menjadi lebih sederhana sehingga memudahkan dalam proses pencernaan enzimatis oleh mikroorganisme rumen. Selain itu, tersedianya nutrien yang cukup dalam cairan rumen in vitro dapat menyebabkan aktivitas mikroorganisme pencerna substrat meningkat (Suksombat et al.,2015) sehingga meningkatkan nilai kecernaan bahan-bahan organik secara in vitro.

\section{KESIMPULAN}

Proses fermentasi kulit singkong dengan menggunakan jamur A.niger dan EM-4 dapat meningkatkan kualitas kulit singkong sebagai bahan pakan ternak karena penggunaan kedua jenis inokulan tersebut dapat meningkatkan kecernaan bahan kering dan bahan organik kulit singkong fermentasi secara signifikan.

\section{DAFTAR PUSTAKA}

Adeleke, B.S., B.J. Akinyele, O.O. Olaniyi, \& Y.A. Jeff-Agboola. 2017. Effect of fermentation on chemical composition of cassava peels. Asian Journal of Plant Science and Research 7(1):31-38.

Antari, R. \& U. umiyasih. 2009. Pemanfaatan tanaman singkong dan limbahnya secara optimal sebagai pakan ternak ruminansia. Wartazoa 19(4):191-199.

Anwar, N., A. Widjaya, \& S. Winardi. 2010. Peningkatan unjuk kerja hidrolisis enzimatik jerami padi menggunakan campuran sellulase kasar dari Trichoderma reesei dan Aspergillus niger. Makara Science 14(2):113-116.
AOAC. 2005. Official Method of Analysis. $11^{\text {th }}$ Ed. Association of Official Analytical Chemist. Washington, DC.

Budiarsana, I.G.M., I.K. Sutama, \& T. Kostaman. 2006. Kajian ekonomi pemanfaatan jerami padi fermentasi sebagai pakan dasar pada ransum kambing Peranakan Etawah jantan muda. Prosiding Seminar Nasional Teknologi Peternakan dan Veteriner "Cakrawala Baru Iptek Menunjang Revitalisasi Peternakan. Pusat Penelitian dan Pengembangan Peternakan Bogor. Bogor, 5-6 September 2006. Hal 575-579.

Iqbal, Z., Y. Usman, \& S. Wajizah. 2016. Evaluasi kualitas jerami padi fermentasi dengan tingkat penggunaan EM-4 yang berbeda. Jurnal Ilmiah Pertanian Mahasiswa Unsyiah 1(1): 655-664.

Jahromi, M.F., J.B. Liang, M. Rosfarizan, Y.M. Goh, P. Shokryazdan, \& Y.W. Ho. 2010. Effect of Aspergillus niger (K8) on nutritive value of rice straw. African Journal of Biotechnology 9(42):7043-7047.

Yildiz, K., B. Dokuzeylul, R. Gonul, \& M. Erman OR. 2017. Cyanide poisoning in cattle. Journal of Dairy and Veterinary Sciences 1(4):1-3.

Mirwandhono, E., I. Bachari, \& D. Situmorang. 2006. Uji nilai nutrisi kulit singkong yang difermentasi dengan Aspergillus niger. Jurnal Agribisnis Peternakan 2(3):91-95.

Mulyono, J., E.G. Said, \& L.B. Hartarto. 1989. Biokonversi, PAU Bioteknologi. Institut Pertanian Bogor. Bogor.

Semaun, R. 2013. Kecernaan in vitrokombinasi fermentasi jerami jagung dan dedak kasar dengan penambahan Aspergillus niger. Jurnal Galung Tropika 2(2):97-102.

Stephanie \& T. Purwadaria. 2013. Fermentasi substrat padat kulit singkong sebagai bahan pakan ternak unggas. Wartazoa 23(1):1522.

Suksombat, W., J. Homkhao, \& C. Meeprom. 2015. Effect of cassava peel replacement for concentrate on ruminal fermentation in rumen-fistulated cows. Proceedings of $36^{\text {th }}$ The IIER International Conference, Bali, Indonesia, $12^{\text {th }}$ Sept, 2015. 
Cabrol, L., A. Marone, E. Tapia-Venegas, J.P. Steyer, G. Ruis-Filippi, \& E. Trably. 2017. Microbial ecology of fermentative hydrogen producing bioprocesses: useful insight for driving the ecosystem function. FEMS Microbiology Reviews 41:158-181.

Telew, C., V.G. Kereh, I.M.Untu, \& B.W. Rembet. 2013. Pengayaan nilai nutritif sekam padi berbasis bioteknologi Effective Microorganisms (EM-4) sebagai bahan pakan organik. Jurnal Zootek 32(5):1-8.

Tilley, J.M.A. \& R.A. Terry. 1963. A two-stage technique for in vitro digestion of forage crop. Journal of The British Grassland Society 18:104-111.

Umiyasih, U. \& Y.N. Anggraeny. 2008. Pengaruh fermentasi Saccharomyces cerevisiae terhadap kandungan nutrisi dan kecernaan ampas pati aren (Arengapinnata MERR.). Prosiding Seminar Nasional Teknologi Peternakan dan Veteriner "Inovasi
Teknologi Mendukung Pengembangan Agribisnis Peternakan Ramah Lingkungan". Pusat Penelitian dan Pengembangan Peternakan Bogor Bogor, 11-12 November 2008. Hlm 241-247.

Wikanastri, H., C.S. Utama, \& A. Suyanto. 2012. Aplikasi proses fermentasi kulit singkong menggunakan starter asal limbah kubis dan sawi pada pembuatan pakan ternak berpotensi probiotik. Prosiding Seminar Hasil-hasil Penelitian 2012. LPPM Universitas Muhammadiyah Semarang. Hal 281-287

Zagrobelny, M., S. Bak, A.V. Rasmussen, B. Jørgensen, C.M. Naumann, \& B.L. Møller. 2004. Cyanogenic glucosides and plant-insect interaction. Phytochemistry 65:293-306.

Zumael, Z. 2009. The Nutrient Enrichment of Biological Processing. Agri med. Warsaw. 